\title{
JOINDER OF CONTROLLING NON-PARTIES: ELIMINATING HIDE-AND-SEEK IN PATENT LITIGATION*
}

If $A$ sues $B$, and $C$ assumes control of the action on behalf of one of the parties, to what extent will the ensuing judgment be determinative of the rights of $C$ ? The statements of courts and commentators suggest the following general rule: one who controls an action will be bound by the adjudicated issues to the same extent as a party of record. ${ }^{1}$ This means that in a subsequent suit between the controlling non-party ${ }^{2}$ and his adversary in the prior action, an estoppel is raised as to those issues. ${ }^{3}$ In order for this rule to be invoked, the non-party must have the right to introduce evidence, examine wit-

*Schnell v. Peter Eckrich \& Sons, Inc., 365 U.S. 260 (1961).

1. Souffront v. Compagnie des Sucreries, 217 U.S. 475 (1910); Ark-Tenn Distributing Corp. v. Breidt, 209 F.2d 359 (3d Cir. 1954); Beyer Co. v. Fleischmann Co., 15 F.2d 465 (6th Cir. 1926) ; Penfield v. C. \& A. Potts \& Co., 126 Fed. 475 (6th Cir. 1903); Restatentent, Judgments $\$ 84$ (1942) [hereinafter cited as Restatemient]; Freeman, JUDGMENTS $§ 432$ (5th ed. 1925). See generally, 139 A.L.R. 1 (1942).

2. For lack of a better term, the one who controls a lawsuit will be referred to as the "controlling non-party," or simply "non-party," denoting a corporation as well as an individual.

3. Courts have attempted to describe this estoppel effect both in terms of res judicata, Tootle v. Coleman, 107 Fed. 41 (8th Cir. 1901) ; David Bradley Mfg. Co. v. Eagle Mfg. Co., 57 Fed. 980 (7th Cir. 1893) ; Clair v. Kastar, 51 F. Supp. 207 (S.D.N.Y. 1943), and collateral estoppel, Empire State Nail Co. v. American Solid Leather Button Co., 71 Fed. 588 (C.C.D.R.I. 1896), 3 Walker, Patents $\$ 684$ (Deller ed. 1937). Res judicata presumes that the parties are concluded "not only as to every matter which was offered and received to sustain or defeat the claim or demand, but as to any other admissible matter which might have been offered for that purpose." Cromwell v. County of Sac, 94 U.S. 351, 352 (1876). Use of the term is compatible with the non-party's right to interpose defenses in the subsequent suit to the extent that such defenses are personal and thus could not be raised while he participated in the name of another. See note 69 infra and accompanying text. On the other hand, the subsequent suit, despite the fact that it poses issues similar to those litigated in the original action, clearly seems to present a different cause of action, Triangle Conduit \& Cable Co. v. National Elec. Prods. Corp., 125 F.2d 1008, 1009 (3d Cir. 1942), Australian Knitting Co. v. Gormly, 138 Fed. 92 (C.C.N.D.N.Y. 1905), Note, 57 HARv. L. Rev. 574, 575 (1944), a situation to which the doctrine of collateral estoppel is more appropriate, Cromwell v. County of Sac, supra at 354. See generally, Scott, Collateral Estoppel By Judgment, 56 HARv. L. Rev. 1, (1942). This precludes in the second suit all those issues actually litigated in the first, but, as opposed to the application of res judicata discussed above, does not preclude those issues which could have been, but were not, raised in the first suit. Id. at 5-7; RESTATEASENT $\$ 68$, comments $d$ and $e$. The justification for this departure from principles of res judicata was expressed in Watts v. Watts, 160 Mass. $464,465,36$ N.E. 479 (1894):

It would be a harsh and oppressive rule which should make it necessary for one sued on a trifling claim to resist it, and engage in costly litigation in order to prevent the operation of a judgment which would be held conclusively to have established against him every material fact alleged and not denied in the declaration, 
nesses, and prosecute an appeal, 4 that is, substantially all the rights of a named party. ${ }^{5}$ But only one whose control is motivated by a proprietary or financial interest in the outcome of the litigation will fall within the rule. ${ }^{6}$ Though, traditionally, control has had to be open and avowed in order for the controlling person or the adverse party to be bound, more recent opinions have held the former to be bound where his participation, concealed during the litigation, is subsequently discovered. ${ }^{8}$ The practice of binding a controlling non-party, although he does not appear on the record, finds justification in the fundamental legal principle that one who has a substantial interest in a subject, and has had an opportunity to direct an action contesting that subject, has been given his day in court as to the issues actually litigated. ${ }^{9}$ The effect of such binding is to

so as to preclude him from showing the truth if another controversy should arise between the same parties.

Because the expenses of litigation may deter the manufacturer from devoting his fullest energies to the defense of a suit against a remote distributor, the application of collateral estoppel instead of res judicata seems warranted.

4. Lovejoy v. Murray, 70 U.S. (3 Wall.) 1, 18-19 (1865) (dictum) ; Note, 65 Harv. L. Rev. 818, 856 (1952). But see Leahy v. Mercantile Trust Co., 296 Mo. 561, 247 S.W. 396 (1922) (non-party bound though denied right to appeal because not a party of record).

5. See FreEMan, JudGMrents $\$ 433$ (5th ed. 1925). But members of a group sponsoring litigation can be bound though all had to submit to the will of the majority and, therefore, no single member had complete control of the defense. Universal Oil Prods. Co. v. Winkler-Koch Eng'r Co., 27 F. Supp. 161 (N.D. I11. 1939); Greenwich Ins. Co. v. N. \& M. Friedman Co., 142 Fed. 944 (6th Cir. 1905). Aware of such decisions, a patent lawyer advises that, when such pooling arrangements are undertaken,

each contributor should be careful to retain no control over the expenditure of the fund and the conduct of the suit, lest he be legally bound by an adverse outcome. However, on finding one of their number about to win, it may be desirable to come immediately into the open and get it into the record . . . HoAR, PATENT TACTICS AND LAW 232 (3d ed. 1950).

6. Restatement $\$ 84$. Comment, 65 Harv. L. Rev. 818, 856 (1952). Describing this same requirement, some courts have spoken in terms of control being undertaken to protect some right or interest of his own. Souffront v. Compagnie des Sucreries, 217 U.S. 475, 487 (1910) ; Dow Chem. Co. v. Metlon Corp., 281 F.2d 292, 297 (4th Cir. 1960). Interest in the decision as a judicial precedent is not sufficient, Bigelow v. Old Dominion Copper Mining \& Smelting Co., 225 U.S. 111 (1912), nor is mere contribution to the defense costs, Rumford Chem. Works v. Hygienic Chem. Co., 215 U.S. 156 (1909).

7. Souffront v. Compagnie des Sucreries, 217 U.S. 475 (1910) ; Lane v. Welds, 99 Fed. 286 (6th Cir. 1899); 2 Black, Jungments $\$ 540$ (1891). Only a rigid adherence to the doctrine of mutuality of estoppel barred the adverse party from offering proof of his opponent's unsuccessfully concealed control. Note, 39 CoLuM. L. REv. 1251, 1252-53 \& n.13 (citation of cases) (1939).

8. Caterpillar Tractor Co. v. International Harvester Co., 120 F.2d 82 (3d Cir. 1941); E.W. Bliss Co. v. Cold Metal Process Co., 1 F.R.D. 193 (N.D. Ohio 1940); Universal Oil Prods. Co. v. Winkler-Koch Eng'r Co., 27 F. Supp. 161 (N.D. Ill. 1939).

9. Standard Acc. Ins. Co. v. Doiron, 170 F.2d 206, 209 (1st Cir. 1948); Restatenent \& 84, comment $a$; United States v. Dollar, 100 F. Supp. 881, 886 (N.D. Cal. 1951), rev'd on other grounds, 196 F.2d 551 (9th Cir. 1952). 
avoid repetitious litigation and to require judicial recognition of those who determined the course of the action.

Most instances of non-party control arise where a stranger to an action has a duty of indemnification toward one of the parties and will, therefore, ultimately carry the burden of a judgment adverse to his indemnitee. ${ }^{10}$ The prototype is the liability insurance contract, where the insurer assumes control of an action by a third party against the insured. ${ }^{11}$ Nevertheless, the important problems of control do not often arise in this area. The consequences of control are only significant because of their effect on a subsequent action between the controlling person and the adverse party. ${ }^{12}$ But in the typical suit under a liability insurance policy, no separate claim exists against the insurer; if the judgment against the insured is satisfied, the question of his control will, therefore, not be raised. ${ }^{13}$

Control is of greatest significance in the area of patent litigation. Typically, a patentee brings an action against a vendor, accused of selling a product which infringes the plaintiff's patent, and the manufacturer of the product, usually bound by contract to save his customer harmless from an infringement suit, ${ }^{14}$

10. See, e.g., Hauke v. Cooper, 108 Fed. 922 (5th Cir. 1901) (warrantor of title to land defended suit against warrantee); Tootle v. Coleman, 107 Fed. 41 (Sth Cir. 1901) (creditor defended sheriff who, given creditor's assurance of protection, attached land later claimed by plaintiff); Marshall Metal Prods., Inc. v. Aghnides, 126 F. Supp. 850 (S.D.N.Y. 1954) (manufacturer contractually bound to defend his distributor in infringement action); RESTATEMENT $\$ 84$, illustration 7 (action against surety defended by principal). But the proprietary or financial interest requisite to a finding of control and an application of estoppel need not derive from a contractual obligation of indemnity. G. \& C. Merriam Co. v. Saalfield, 241 U.S. 22 (1916) (publisher who received royalties on sale of dictionaries defended distributor in copyright suit); Overman Cushion Tire Co. v. Goodyear Tire \& Rubber Co., 48 F.2d 213 (S.D.N.Y. 1930) (suit against subsidiary defended by parent company).

11. See, e.g., State Farm Mut. Auto. Ins. Co. v. Coughran, 303 U.S. 485 (1938); Shelby Mut. Cas. Co. v. Richmond, 185 F.2d 803 (2d Cir. 1950).

12. Though a finding of control may significantly affect the outcome of a suit between the controlling non-party and the named party receiving the benefit of such control, such actions are less frequent and without the scope of this discussion. For citation of cases, see 139 A.L.R. 1, 10 (1942).

13. Under commonly accepted tort principles, a satisfied judgment bars any further recovery on the same claim.

But if the insurance company has undertaken to control the insured's defense, and an adverse judgment remains unsatisfied, some cases have allowed the injured party to hold the insurer directly liable in a subsequent garnishment proceeding on the basis of the company's control of the litigation. See, e.g., Patterson v. Adan, 119 Minn. 308, 138 N.W. 281 (1912). See VANCE, Insurance $\$ 135$, at 803 \& n.18 (3d ed. 1951) (citing cases). In these cases, proof of control would clearly be an element essential to recovery.

14. See Note, 72 Harv. L. Rev. 328, 332 (1958). See generally, Poole, Patcut Protection Clauses in Printed Purchase Orders and Acknowledgment Forms, 39 J. PAT. OFF. Soc'y 83 (1957). 
assumes control of the action. ${ }^{15}$ The patentee, upon resolution of this action, still retains a separate cause of action against the manufacturer, even though infringement is charged against the same product. ${ }^{16}$ If this second action is pursued, its outcome may be significantly affected by a finding that control existed in the first suit. ${ }^{17}$

Practical considerations peculiar to patent litigation help to explain the frequency with which the issue of control arises in the patent field. In perhaps no other field is there such a clearly defined and widely recognized disparity in the attitudes and holdings of the different circuits, ${ }^{18}$ and in no other field is the resulting temptation to forum-shop so easily gratified. Given these circumstances, and the fact that an infringement suit will usually be prosecuted most profitably and most effectively against the manufacturer of the infringing article, the patentee will often succeed in accomplishing by indirection that which he might otherwise fail to accomplish by a suit directly against the manufacturer. Thus, if the manufacturer is amenable to suit only in a jurisdiction regarded as hostile to patents, the patentee, aware that the manufacturer will probably assume control of an infringement action against a distributor, need only seek a friendlier jurisdiction in which the product is sold and there institute suit against a user or distributor. ${ }^{19}$ If the patentee receives a favorable decree, he is free to bring suit in the manufacturer's district and, if he can prove control, ${ }^{20}$ to preclude the manufacturer from reopening those issues ad-

15. See, e.g., S.S. Kresge Co. v. Winget Kickernick Co., 96 F.2d 978 (8th Cir. 1938); Warford Corp. v. Bryan Screw Mach. Prods. Co., 44 F.2d 713 (6th Cir. 1930); Brock v. Brown, 130 F. Supp. 628 (D. Md. 1956).

16. "[T] he cause of action of a patent owner against an infringing manufacturer is wholly separate and distinct from his cause of action against one who resells the infringing product." Triangle Conduit \& Cable Co. v. National Elec. Prods. Corp., 125 F.2d 1008, 1009 (3d Cir. 1942).

17. If it is found that the manufacturer controlled the first suit, he and the patentee will be estopped, by principles of collateral estoppel, see note 3 supra, from relitigating any of the matters argued in that suit.

18. See Lang \& Thomas, Disposition of Patent Cases by Courts During the Period 1939 to 1949, 32 J. PAT. OFF. Soc'Y 803 (1950), which compares the percentage of patents invalidated in each circuit. The article points out, for example, that between 1945 and 1949, patentees lost 94\% of their suits in the Eighth Circuit and only 23\% in the Fifth Circuit. Id. at 807.

19. See Seidel, Patent Litigations, 1 Prac. Law. 49, 51 (March 1955) ; Hoar, Patent TActics AND LAw 225 (3d ed. 1950) ("Very often a desirable venue can be obtained by suing a distributor or customer of the real infringer.") The courts have not remained unaware of the reasons behind the abundance of suits against distributors instead of manufacturers. Bros, Inc. v. W. E. Grace Mfg. Co., 261 F.2d 428, 430 (5th Cir. 1958); Rayco Mfg. Co. v. Chicopee Mfg. Corp., 148 F. Supp. 588, 590-91 (S.D.N.Y. 1957).

20. There is some conflict within the federal courts as to the means by which control is proved. Courts have sometimes included in the decree a statement to the effect that the defense was controlled by another person. E.g., RCA v. E. J. Edmond \& Co., 20 F.2d 929 (S.D.N.Y. 1927) ; Brock v. Brown, 138 F. Supp. 628 (D. Md. 1956) ; Eagle Mfg. Co. v. Miller, 41 Fed. 351 (C.C.S.D. Iowa 1890), rev'd on other grounds, 151 U.S. 186 (1891). Exactly what legal effect this finding would have in a subsequent action by the 
judicated in the prior suit. ${ }^{21}$ The patentee has thereby succeeded in litigating the most crucial elements of a patent infringement suit in a jurisdiction of his own choosing. ${ }^{22}$ The possibility that the distributor, effectively immune from liability under the judgment, ${ }^{23}$ will not present the strongest case in defense, and the likelihood that an adverse judgment would seriously endanger the reputation of the product, ${ }^{24}$ motivates the manufacturer to assume control over the litigation. ${ }^{25}$ If he then receives a favorable judgment, the manufac-

plaintiff against the controlling non-party is not certain. In purely in personam actions, courts would seem to have the power to make conclusive findings only against those who are parties to the action and only as to those issues on which both parties have had an opportunity for a full hearing. Galpin v. Page, 85 U.S. (18 Wall.) 350,368 (1873). With this problem in mind, Judge Learned Hand, speaking for the court in MinneapolisHoneywell Regulator Co. v. Thermoco, Inc., 116 F.2d 845 (2d Cir. 1941), deleted from the lower court's decree a comment on the manufacturer's control of the defense, it being unnecessary "to the disposition of the case between the parties." Id. at 848. Attempting to distinguish N.O. Nelson Mfg. Co. v. Myers \& Bros. Co., 25 F.2d 659 (6th Cir. 1928) as a case in which the fact of control was noted in the original judgment, the court became involved in the rather tortuous distinction between "record of fact" and "finding of fact." 116 F.2d at 847. The court seemed to be suggesting that the "fact" of control mentioned in such judgments was not conclusive in a later suit. At least one court has explicity taken this position. Marshall Metal Prods. Inc. v. Aghnides, 126 F. Supp. 850 (S.D.N.Y. 1954).

Subsequent decisions have assumed that Mimneapolis-Honeywell renders improper any inquiry into control in the orginal action. Maulsby v. Conzevoy, 161 F.2d 165 (9th Cir. 1947) ; Lip Lure, Inc. v. Bloomingdale Bros., Inc., 27 F. Supp. 811 (S.D.N.Y. 1939) (Federal Rule 34 cannot be invoked to prove non-party control); Prosperity Co. v. Saint Joe Machs., Inc., 2 F.R.D. 299 (W.D. Mich. 1942). Contra, Aghnides v. S.H. Kress \& Co., 140 F. Supp. 582,587 (1956). The existence of control is properly considered in a later action against the controlling non-party, for it raises issues of fact as to which evidence may be adduced and a trial before a jury may be had. See Marshall Metal Prods., Inc. v. Aghnides, 126 F. Supp. 850 (S.D.N.Y. 1954) ; Dillard v. McKnight, 34 Cal. $2 \mathrm{~d}$ 209, 209 P.2d 387 (1949).

21. See note 17 supra.

22. The popularity of this practice is evidence of the ease with which patentees circumvent Congress' intended limitation upon choice of venue set out in $\$ 1400$ (b) (quoted at note 35 infra).

23. Bros, Inc. v. W.E. Grace Mfg. Co., 261 F.2d 428 (5th Cir. 1958); 4 Moore, Federal Practice $\int$ 24.09, at 50 (1948) [hereinafter cited as MOORE].

24. In the same way that "every patent owner has an interest in keeping the reputation of his patent from the stain of a judgment of invalidity" even though such judgment will not conclude him directly, A.I. Smith Iron Co. v. Dickson, 141 F.2d 3, 6(2d Cir. 1944), a manufacturer will wish to avoid an adjudication of infringement against his product. If the finding of infringement is made against a seller or user of the product, it will not bind the manufacturer in a subsequent suit. But it is likely that potential customers will be discouraged from purchasing a product the use or sale of which may subject them to an infringement suit. Although the manufacturer might offer protection in such suits, the customer would still be denied the right to use or sell the product should it be held to infringe.

25. Naturally, circumstances may be such that the manufacturer will not wish to incur the expenses of litigation and will merely pay whatever damages are assessed 
turer can not only plead that judgment in estoppel if subsequently sued by the patentee, ${ }^{26}$ but he could intervene in later suits against his customers and have them dismissed as well. ${ }^{27}$

Formal intervention, often available to the manufacturer under the Federal Rules, ${ }^{28}$ presents a possible alternative to control. Though all the privileges of control would inure to an intervening manufacturer, this course of action is not without its disadvantages. Intervention may subject him to direct liability for his own acts of infringement ${ }^{29}$ as well as indirect liability for those

against the distributor. See, e.g., I.T.S. Rubber Co. v. Essex Rubber Co., 272 U.S. 429 (1926). But if he fails to defend that suit and the validity of the patent is upheld, he might well find it more difficult to defend if later sued directly. Though the decision of another court on the patent will not be binding against a different defendant "as a case of stare decisis," Aeration Processes, Inc. v. Lange, 196 F.2d 981, 982 (8th Cir. 1952), the court may find the prior adjudication "strongly persuasive under the doctrine of comity." Williams v. Hughes Tool Co., 186 F.2d 278, 281 (10th Cir. 1950). Accord, Koolvent Metal Awning Corp. of America v. Graham, 82 F. Supp. (N.D. Ohio 1948).

26. E.g., E.I. DuPont de Nemours v. Sylvania Industrial Corp., 122 F.2d 400 (4th Cir. 1941) (manufacturer defended distributor in trademark suit); Doherty Research Co. v. Universal Oil Prods. Co., 107 F.2d 548 (7th Cir. 1939).

27. Continuous Extract Press Corp. v. Eastern Cotton Oil Co., 264 Fed. 340 (E.D.N.C. 1920). See also, Kessler v. Eldred, 206 U.S. 285 (1907).

28. FED. R. CIv. P. 24. The manufacturer does not have an absolute right to intervene, 4 MOoRe $\{24.09$, and the court may deny him this privilege if it feels that intervention would enlarge the scope of the litigation, Finch v. Gilman Bros. Co., 11 F.R.D. 198 (D. Conn. 1951), or if there is no showing that the intervener's interests will not otherwise be adequately represented, Union Nat'l Bank v. Superior Steel Corp., 9 F.R.D. 124 (W.D. Pa. 1949). But absent similar circumstances, the manufacturer has usually been permitted to intervene. Chandler \& Price Co. v. Brandtjen \& Kluge, Inc., 296 U.S. 53 (1935); Foote v. Parsons Non-Skid Co., 196 Fed. 951 (6th Cir. 1912) ; Wenborne-Karpen Dryer Co. v. Dort Motor Car Co., 300 Fed. 404 (E.D. Mich. 1924) ; Curran v. St. Charles Car Co., 32 Fed. 835 (E.D. Mo 1887).

29. Apparently this point has not been decided. It is arguable, at least, that the patent venue statute, see note 35 infra, would bar inquiry into the manufacturer's offense. On the other hand, the act of intervention might reasonably be construed as a waiver of the privilege accorded by the statute. Two considerations support this construction. First, once a court has acquired jurisdiction over a controversy, the venue statute cannot be invoked to defeat a counterclaim. 3 MOORE $\{13.22$. Second, the claim against the manufacturer would present issues of fact and law closely similar to those involved in the original complaint, and thus would hardly expand the scope of the litigation. Support, by analogy, is found in a case in which the government was joined as a third-party defendant under Federal Rule 14(a). Abramovitch v. United States Lines, 174 F. Supp. 587 (S.D.N.Y. 1959). When the plaintiff then attempted to amend his complaint in order to obtain damages from the government, it was argued that venue was improper for that claim. The court allowed the amendment, saying that the venue statute should not apply to a claim by a plaintiff against a third-party defendant. Moore suggests a similar result. 3 MOORE ๆ 14.28 [3]. The limitation in carrying this reasoning over to intervention is that under Rule 14(a), the plaintiff's claim against the third-party defendant must arise "out of the transaction or occurence" which is the subject matter of the original action, over which the court already has asserted jurisdiction, while the patentee's claim against the intervening manufacturer would be a separate cause of action, albeit presenting a common question of law or fact as required by Rule 24 (b) (2). 
of the distributor, while denying him the right to assert counterclaims independent of those available to the original defendant. ${ }^{30}$ Perhaps even more important, if, through intervention, the manufacturer became a party, he would have no alternative but to finish the litigation or submit to the judgment. As a controlling non-party, however, he is free to evaluate the trend of the proceedings and, if circumstances warrant, to conceal his control or withdraw completely, perhaps thereby avoiding a finding of control which would bind him in subsequent litigation. ${ }^{31}$

On occasion, however, the patentee has attempted to join the manufacturer as a party in the original suit by requesting the court to consider his control a general appearance. ${ }^{32}$ In Schnell $v$. Peter Eckrich \& Sons, Inc., ${ }^{33}$ plaintiff brought suit in Indiana against a user of an allegedly infringing product and attempted to join an Illinois manufacturer prior to trial, the latter admitting control of the defense. The district court, affirmed by a divided Court of Appeals, ${ }^{34}$ granted the motion to quash service and dismissed the manufacturer

30. The leading case is Chandler \& Price Co. v. Brandtjen \& Kluge, Inc., 296 U.S. 53 (1935), in which a manufacturer intervened in an infringement action against one of his distributors and counterclaimed on the basis that the patentee's device infringed one of the manufacturer's products. In dismissing the counterclaim, the court said that the

intervenor was not entitled to come into the suit for the purpose of having adjudicated a controversy solely between it and plaintiff. Issues tendered by or arising out of plaintiff's bill may not by the intervenor be so enlarged. It is limited to the field of litigation open to the original parties. Id. at 57-58.

Accord, Angier v. Anaconda Wire \& Cable Co., 48 F.2d 612 (D. Del. 1931). At least one writer has argued that the Federal Rules have broadened the intervenor's right to counterclaim. Willis, Procedure in Patent Cases Under the New Federal Rules, 30 Geo. L.J. 348, 357 (1942). Moore contends that if general intervention has been allowed, the intervenor has the same right of counterclaim as an original party. 4 MOORE $\llbracket 24.17$, at 127.

31. No cases have been found addressing themselves to the situation where a controlling non-party discontinues his control in the hope of avoiding a finding of control and the consequent estoppel effect of an unfavorable judgment. The argument in his favor would be that he did not receive a full hearing on all the issues and thus is not subject to the decree. But there should clearly come a point in the proceedings when his conduct up to that time would be sufficient to establish control, whether or not he subsequently withdrew. Otherwise, the controlling non-party would have a distinct advantage in being able to evaluate the litigation as it proceeded and terminate his control if he anticipated an adverse decision. The simplest and perhaps fairest solution would be to say that once the non-party has assumed control of the defense, subsequent withdrawal from the action will not protect him from the consequences of the judgment. If we assume that control was originally undertaken in selfinterest, see notes 24 and 25 supra and accompanying text, then the non-party should no more be able, by withdrawal, to avoid a final judgment than should a party.

32. See, e.g., Dow Chem. Co. v. Metlon Corp., 281 F.2d 292 (4th Cir. 1960) ; S.S. Kresge Co. v. Winget Kickernick Co., 96 F.2d 978 (8th Cir. 1938); Freeman-Sweet Co. v. Luminous Unit Co., 264 Fed. 107 (7th Cir. 1920).

33. 365 U.S. 260 (1961).

34. Schnell v. Peter Eckrich \& Sons, Inc., 279 F.2d 594 (7th Cir. 1960). Appeal was allowed pursuant to 28 U.S.C. $\$ 1292$ (b) (1958), the district court having certified that the order dismissing the manufacturer from the suit involved a controlling question of law and an appeal would materially advance the ultimate determination of the litigation. 
from the action. The Supreme Court unanimously affirmed, holding that, under the patent venue provision of the United States Code, ${ }^{35}$ Indiana was an improper venue for suit against the manufacturer. The Court considered itself bound by the "clear and specific" 36 legislative mandate of section 1400(b), a statute described in a prior opinion as "the sole and exclusive provision controlling venue in patent infringement actions." 37 Denying that it was exalting form over substance, the Court held that it could not ignore the unambiguous language of the statute in favor of some overriding public policy. ${ }^{38}$

Presumably, the Court emphasized the purpose and meaning of section 1400 (b) in order to demonstrate that waiver of venue is not to be lightly assumed in patent cases. But notwithstanding this emphasis, the fact remains that venue is only a "privilege ... [which] may be lost . . . by submission through conduct."30 The determination of whether or not this privilege has been lost should be based upon analysis of the conduct involved, viewed against the background of the appropriate legislative policy. If Congress had indeed considered the problem of non-party control in passing 1400 (b), then the Court's reluctance to countenance this means of avoiding the clear legislative mandate would have been justified. But despite the obvious implication of the Court's statement that "the practice complained of here was not at all unusual at the time of this statute's passage,"40 House debate on the bill gives no indication that the practice of non-party control in patent suits had ever been brought to the attention of Congress. ${ }^{41}$ And even if Congress had been made aware of this practice, it is hardly likely that the threat of joining a nonparty would have been considered any more deserving of legislative intervention than was the entire practice of non-party control which so freely permitted patentees to circumvent the restrictions of $1400(\mathrm{~b}) .^{42}$ It might be further argued that if Congress limited the appropriate venue for infringement suits because of serious concern about protecting alleged patent infringers from being sued in remote and inconvenient forums, a very restrictive approach to waiver of 1400 (b) would be justified. The reasoning would be that waiver of venue should not be readily inferred where it appears that Congress had considered the possible abuses which might result from an increase of the available forums for instituting patent suits. But legislative history again fails to support the Court's position. The reports disclose that the House was

\section{28 U.S.C. $\$ 1400$ (b) (1958) provides as follows:}

Any civil action for patent infringement may be brought in the judicial district where the defendant resides, or where the defendant has committed acts of infringement and has a regular and established place of business.

36. Schnell v. Peter Eckrich \& Sons, Inc., 365 U.S. 260, 262 (1961).

37. Fourco Glass Co. v. Transmirra Prods. Corp., 353 U.S. 222, 229 (1957).

38. Schnell v. Peter Eckrich \& Sons, Inc., 365 U.S. 260, 265 (1961).

39. Neirbo Co. v. Bethlehem Shipbuilding Corp., 308 U.S. 165, 168 (1939).

40. Schnell v. Peter Eckrich \& Sons, Inc., 365 U.S. 260, 262-63 (1961).

41. 29 Cong. Rec. 1900 (1897).

42. See note 22 supra and accompanying text. 
aware of a conflict of decisions in the federal courts, ${ }^{43}$ some of which had allowed venue wherever the infringer could be found, regardless of where his established place of business was located or where the infringement had taken place. ${ }^{44}$ At least one decision, however, had confined jurisdiction to the district in which the infringer resided, ${ }^{45}$ a serious handicap to a patentee when the infringment occurred at a considerable distance from that residence. Congress was apparently motivated to "define the exact jurisdiction of the federal courts in actions to enforce patent rights" 46 by a desire to resolve this conflict among the circuits, and not by a desire to limit the expansive nature of patent venue. Section $1400(b)$, the statutory resolution of this conflict, adopted a position intermediate to the extremes represented by the conflicting cases.

In this light, 1400 (b) does not appear to express any clear congressional attitude towards the practice of control. The Court, therefore, might reasonably have inquired further into the nature of the manufacturer's conduct to determine whether his joinder would have, in fact, contravened the general policy underlying the venue requirement. Such was the inquiry made in Neirbo Co.v. Bethlehem Shipbuilding Corp., ${ }^{47}$ in which a narrow reading of an equally "clear and specific" venue statute would have prohibited jurisdiction. 4 sut in that case the Court said that one who had consented to service of process in a given state had waived his objections to federal venue in that state. ${ }^{40}$ As a result it was held that the defendant could be sued in a district where service was proper although it was not, as the venue statute required, "the residence of either the plaintiff or the defendant." more have been "an intrusion into the legislative field" 51 than was the comparable finding in Neirbo. In fact, such a finding would be in strict accord with the Neirbo Court's observation as to the nature of venue : "the locality of a law suitthe place where judicial authority may be exercised-though defined by legislation relates to the convenience of the litigants and as such is subject to their disposition." ${ }^{32}$ The manufacturer could hardly be heard to complain about the in-

43. 29 Cong. Rec. 1900 (1897) (remarks of Mr. Mitchell).

44. Earl v. Southern Pac. Co., 75 Fed. 609 (C.C.N.D. Cal. 1896); National Button Works v. Wade, 72 Fed. 298 (C.C.S.D.N.Y. 1896) ; Smith v. Sargent Mfg. Co., 67 Fed. 801 (C.C.S.D.N.Y. 1895).

45. Halstead v. Manning, Bowman \& Co., 34 Fed. 565 (C.C.S.D.N.Y. 1888). A full list of the cases which prompted the bill is set out at 29 CoNG. Rec. 1901 (1897).

46. Stonite Prods. Co. v. Melvin Lloyd Co., 315 U.S. 561, 565 (1942).

47. 308 U.S. 165 (1939).

48. The statute required that diversity actions be brought in the district wherein either the plaintiff or the defendant resided. 25 Stat. 434 (1888) (now 28 U.S.C. \$1391(a) (1958)). The action, based on diversity, was tried in New York, although neither of the parties was a resident of that state. Neirbo Co. v. Bethlehem Shipbuilding Corp., 30S U.S. 165,167 (1939).

49. The defendant had been required by state law to appoint an agent to receive service of process. The Court held that this consent to be sued in the state courts extended to the federal courts within that state, objections to venue notwithstanding. Id. at 175 .

50. 25 Stat. 434 (1888) (now 28 U.S.C. $\S 1391$ (a) (1958)).

51. Schnell v. Peter Eckrich \& Sons, Inc., 365 U.S. 260, 263 (1961).

52. Neirbo Co. v. Bethlehem Shipbuilding Corp., 308 U.S. 165, 168 (1939). 
convenience of venue in a forum in which he is already fully participating on behalf of a party. If, then, convenience to the litigants, the essence of venue, ${ }^{53}$ is not a significant factor in Schnell, 1400 (b) should hardly be dispositive of the problem ; other considerations, looking both to relevant judicial pronouncements and to the possible consequences of joinder, should govern instead. ${ }^{54}$

Previous courts, confronted with situations seemingly indistinguishable from that presented in Schnell, have, with few exceptions, declined to extend their jurisdiction over the non-party. ${ }^{55}$ The exceptions are in large part attributable to the misconstruction of an early federal case, Eagle Mfg. Co. v. Miller.50 In response to a request by the patentee that the judgment run against the controlling manufacturer, the court stated in its decree that the manufacturing corporation was the principal party in interest and thus as fully "bound by the results ... of the litigation" as if it were a party of record; "for that, in effect, is only stating, in set phrase, the force which the decree would in fact have as against the corporation."57 Despite a persuasive argument by another federal court six years later that Eagle had only intended to prescribe the usual estoppel effects of non-party control, ${ }^{58}$ a few courts have cited the case as support for allowing a decree to run directly against a non-party. ${ }^{59}$ The

53. See generally, 1 MOoRe ๆ 0.140 .

54. It would seem that so long as Schnell remains good law, joinder of the non-party in patent litigation would be largly precluded. But cases in which $\$ 1400(\mathrm{~b})$ was not determinative would not be ruled by the Court's opinion in Schnell. This would include all cases of control outside the patent field, see note 10 supra, and those patent suits in which the controlling manufacturer did business within the forum state, thus satisfying the venue statute, but for some reason had not been properly served.

55. E.g., Overman Cushion Tire Co. v. Goodyear Tire \& Rubber Co., 48 F.2d 213 (S.D. N.Y. 1930), aff'd per curiam, 48 F.2d 215 (2d Cir. 1931); Brock v. Brown, 138 F. Supp. 628 (D. Md. 1956) ; Van Kannel Revolving Door Co. v. Winton Hotel Co., 263 Fed. 988 (N.D. Ohio 1920). But see, cases cited at note 59 infra.

56. 41 Fed. 351 (S.D. Iowa 1890), rev'd on other grounds, 151 U.S. 186 (1894).

57. Id. at $357-58$.

58. In Bidwell v. Toledo Consol. St. Ry., 72 Fed. 10 (N.D. Ohio 1896) the court argued that the decree in Eagle "bound" the manufacturer only insofar as it constituted an estoppel in future litigation. It was towards this end alone that the decree recorded the manufacturer's participation, for the cases cited in the opinion could support no broader interpretation of the decree.

59. Dicks Press Guard Mfg. Co. v. Bowen, 229 Fed. 193 (N.D.N.Y. 1916), in permitting joinder of a controlling manufacturer, cited Eagle as its only support. A subsequent decision, Radio Corp. of America v. E.J. Edmond \& Co., 20 F.2d 929 (S.D.N.Y. 1927), in denying a similar motion, ruled that Dicks Press could not control because the patentee's motion in that case had been unopposed, and the court had not been referred to a controlling precedent, Parsons Non-Skid Co. v. E.J. Wallis Co., 176 Fed. 176 (S.D.N.Y. 1909).

Again in reliance on Eagle, as well as Dicks Press, as sole federal authorities, the court in Ocean Acc. \& Guar. Corp. v. Felgemaker, 143 F.2d 950 (6th Cir. 1944), allowed a controlling insurance company to be joined as a party, holding that the company, by its control, had effectively appeared in the action and submitted to the court's jurisdiction. But factors in addition to control might have influenced the court's decision. An Ohio statute, Generax. Code of Ohio, § 9510-4 (now Ohio Rev. Code Ans. § 3929.06 (1953)), 
problem was brought before the Supreme Court in G. \& C. Merriam Co. v. Saalfield, ${ }^{60}$ a case quoted extensively by the Court in Schnell. An action for copyright infringement was brought against Saalfield, distributor of a dictionary published by Ogilvie. Following trial but prior to the entry of a final decree, plaintiff sought by means of a supplemental bill, to join Ogilvie, who was allegedly controlling the defense. The Court affirmed the district court's dismissal of the bill, though the grounds of the decision are unclear. The opinion does state-apparently in dictum-that control by itself is not sufficient to bring one within the court's in personam jurisdiction. ${ }^{61}$ Later federal cases, addressing themselves specifically to this point, have generally concurred. ${ }^{62}$.

The question raised in Schnell, however, cannot be directly answered by the precedents. Whereas in Schnell the patentee attempted to join the manufacturer before commencement of the trial, in the previous suits the request to bind the controlling non-party by an in personam decree came at the conclusion of the proceedings. ${ }^{63}$ Nevertheless, though confronted only with post-trial requests to bind, these courts wrote in terms so broad as to imply disapproval of all efforts to join, regardless of the point at which they were made. ${ }^{64}$ In the pre-Schnell cases, the plaintiff in effect asked that the court

provided for direct action against the insurer when a judgment against the insured remained unsatisfied, and a clause in the insurance contract made the company directly liable to the insured's judgment creditor. In addition, the amount of damages against the company was already fixed by the award against the insured, and the company conceded that it had no defenses but the jurisdiction question. Though these considerations hardly answer the jurisdictional objections, see notes 68-71 infra and accompanying text, they might well have led the court to conclude that the merits of the controversy between the company and the plaintiff had been substantially resolved and that a second action between the judgment creditor and the insurer would be a mere formality.

In allowing a decree to run against a controlling manufacturer, the court in Redman v. Stedman Mfg. Co., 154 F. Supp. 378 (M.D.N.C. 1957), aff'd, 257 F.2d 867 (4th Cir. 1958), enforced, 181 F. Supp. 5 (M.D.N.C. 1960), remained within this succession of cases by drawing strong support from Ocean Accident. But the manufacturer failed to attack that portion of the decree on appeal, and that same Court of Appeals has since held, Dow Chem. Co. v. Metlon Corp., 281 F. 2d 292 (4th Cir. 1960), that control does not permit one to be made a party

60. 241 U.S. 22 (1916).

61. Id. at 29.

62. See cases cited at note $\mathbf{5 5}$ supra.

63. Ibid.

64. In Gulf Smokeless Coal Co. v. Sutton, Steele \& Steele, 35 F.2d 433 (4th Cir. 1929), the court said that

the fact that one has assumed and is conducting the defense of a patent infringement suit in behalf of the defendant does not justify his being made a party defendant in derogation of ... [\$1400(b) ].

These words were cited with approval in Dow Chem. Co. v. Metlon Corp., 281 F.2d 292, 298 (4th Cir. 1960). See Overman Cushion Tire Co. v. Goodyear Tire \& Rubber Co., 48 F.2d 213, 214 (S.D.N.Y. 1930) ; Parsons Non-Skid Co. v. E.J. Willis Co., 176 Fed. 176 (S.D.N.Y. 1909) ; Freeman-Sweet Co. v. Luminous Unit Co., 264 Fed. 107 (7th Cir. 1919). 
look behind the formal record and note the extent of the non-party's participation. It was argued that, in exercising complete control over the defendant's suit, such person had a full opportunity to be heard and therefore effectively submitted himself to the court's jurisdiction. With near unanimity and a conspicuous absence of reasoned analysis, court after court announced the dogma that one does not make a general appearance by conducting a lawsuit in behalf of a nominal party. ${ }^{65}$ The force of the judgment, as one court put it,

does not go beyond creating an estoppel in subsequent litigation between ... [the controlling non-party and his adversary] concerning the same matters. ... [Control] does not make ... [the non-party] a party to the prior suit. ${ }^{\text {eg }}$

Perhaps the result reached in these cases reflected a vague, but not entirely baseless, reluctance to render a judgment against one who had not been named in the complaint and who had neither filed an answer nor made argument in his own name. ${ }^{67}$ The courts, moreover, may have been troubled by the prospect of permitting a personal judgment to issue from proceedings during which the person had not been formally brought within the court's jurisdiction. ${ }^{68}$ If these reservations indeed underlay the courts' decisions-and they hardly found their way into written opinions-they still do not satisfy, for they are only expressions of legalistic conclusions not independently persuasive. It is hardly appropriate to talk in traditional terms when referring to the distinctly unique phenomenon of non-party control. How meaningful is it to argue that the controlling non-party is not subject to the court's jurisdiction or is not appearing in his own name when his interests are being effectively represented in open court, and when another court, in recognition of that fact, makes the judgment conclusive upon him as to those issues actually litigated? This need not invalidate the concepts of appearance, jurisdiction, and parties in this area; it is only meant to imply that when an attempt is made to employ these concepts outside of their historical context, inquiry must be made into their underlying purpose.

Had this course been followed, the courts might well have found cogent support for their conclusions. For a real threat to due process was, in fact, presented by the attempted post-trial joinder of the non-party in that such joinder would have infringed his right to a full hearing. During the course of the trial, the non-party, because he is participating only in behalf of the named

65. Ibid.

66. S.S. Kresge Co. v. Winget Kickernick Co., 96 F.2d 978, 989 (8th Cir. 1938)..

67. See 1 BLACK, JUDGMENTS $\S 219$ (1891). But that courts may fruitfully probe the substance beneath these formalities is borne out by the result in Louisville \& Nashville R.R. v. Schmidt, 177 U.S. 230 (1900), discussed at note 71 infra.

68. See, c.g., National Exch. Bank v. Wiley, 195 U.S. 257, 269 (1904) :

It is thoroughly settled that a personal judgment against one not before the court by actual service of process, or who did not appear in person or by an authorized attorney, would be invalid as not being in conformity with due process of law. 
defendant, is restricted to raising only those defenses available to the defendant. Any defense which might ordinarily be available to him but not to the defendant may, therefore, not be asserted. ${ }^{69}$ Assuming that the full hearing requirement of due process guarantees a party the right to present all relevant defenses, ${ }^{70}$ joinder of the controlling non-party at the end of the trial, during which he has been unable to plead personal defenses, would be constitutionally prohibited. ${ }^{71}$

None of the arguments advanced as a basis for the courts' decisions rejecting attempted post-trial joinder would militate against attempts to join prior to trial; one who was joined at that time would be formally before the court throughout the proceedings and would naturally be accorded the full rights of a party. If any of these arguments did in fact influence the courts, the breadth of their decisions seems only to indicate an absence of consideration rather than a disapproval of pre-trial attempts to join. On the other hand, the courts' refusal to include controlling non-parties within their decrees does not mean that they failed to recognize the very real sense in which non-parties had made substantial use of the judicial process to protect their own interests. In fact, to the extent that courts did impose the consequences of collateral estoppel upon the controlling non-party, it was recognized that, as to the issues actually litigated, such non-party had had the same opportunity to be heard as a party. $^{72}$ If, then, non-parties were given an opportunity to be heard on all

69. Since he is not a party of record, the non-party has no right to make defenses which he alone can assert. Thus, in Caterpillar Tractor Co. v. International Harvester Co., 32 F. Supp, 304 (D. N.J. 1940), the court found that the controlling manufacturer could not have raised the defenses of laches and estoppel in the original suit because they could not be claimed by the named defendant, his distributor. They were, therefore, available to him in a subsequent suit in which he was named as a defendant. But see Warford Corp. v. Bryan Screw Mach. Prods. Co., 44 F.2d 713 (6th Cir. 1930).

70. See generally, Brinkerhoff-Faris Trust \& Sav. Co. v. Hill, 281 U.S. 673 (1930); Postal Telegraph Cable Co. v. City of Newport, 247 U.S. 464, 476 (1918).

71. But see Louisville \& Nashville R.R. v. Schmidt, 177 U.S. 230 (1900), where it was held that, though not a named party in the action, the Louisville \& Nashville had had an opportunity to present all defenses. The Supreme Court felt itself bound by the Kentucky court's finding that the railroad, by virtue of its ownership of the disputed property, its control over the litigation, and the substantial liquidation of the nominal defendant, had made itself the real defendant, having been an actor in the state courts and having sought by all available means to defeat the complaint. See Schmidt v. Louisville, C. \& L. Ry., 99 Ky. 143, 35 S.W. 135 (1896). The Court refused to find that the Louisville \& Nashville had been denied the right to litigate personal defenses when none had in fact been proffered. In addition,

the Louisville \& Nashville was made a party defendant to the rule [to show cause] in the most technical sense, and was actually served. It made answer and asserted its setoff. The mere fact that the proceeding to hold it liable was by rule does not conflict with due process under the Fourteenth Amendment, for, as we have seen, forms of procedure in the state courts are not controlled by the Fourteenth Amendment, provided the fundamental rights secured by the amendment are not denied. Louisville \& Nashville R.R. v. Schmidt, 177 U.S. 230, 238 (1900).

72. See note 9 supra and accompanying text. 
issues and appeared as named defendants throughout, there would seemingly be no due process objection to subjecting them to the court's judgment; when this is accomplished by joinder before trial, it represents but a short and logical step from present judicial treatment of controlling non-parties.

Concededly, the traditional notions of service of process and general appearance, the methods by which jurisdiction has been historically invoked, ${ }^{73}$ do not justify extension of the court's jurisdiction over the controlling non-party. The nonresident manufacturer is, by hypothesis, beyond the reach of the court's process. ${ }^{74}$ And however much the manufacturer's extensive use of the courts to protect his own interest might resemble the sine qua non of a general appearance, namely argument to the merits, ${ }^{75}$ such an appearance was traditionally entered only by one who was named in the complaint and who argued before the court in his own name. ${ }^{78}$ But even if the manufacturer's actions do not come within the strict requirement of a general appearance, jurisdiction should not thereby be precluded. The court's right to extend its jurisdiction to a controlling non-party should depend on a consideration of the over all character of his conduct. And inquiry in this direction leads to the observation that the non-party acts in a way normally reserved for parties of record. It is hardly a distortion of jurisdictional concepts to bring formally before the court one who has made or admits intent to make full use of its processes in his own interest. Indeed, it may be argued that the assertion of jurisdiction over the controlling non-party can find justification in a realistic approach to the meaning of general appearance. The term "general appearance" states a legal conclusion, ${ }^{77}$ merely signifying that a person has taken sufficient action before the court so that it will exercise in personam jurisdiction without valid service of process. So viewed, the term is appropriately applied to the situation of non-party control.

73. Pennoyer v. Neff, 95 U.S. 714, 733 (1877).

74. The fact that the manufacturer is represented by counsel through the nominal defendant is unimportant. As a matter of judicial convenience, courts grant immunity from service of process to attorneys who are in a jurisdiction conducting another action. See 2 MOORE \ 4.20.

75. See, e.g., Southern Lands, Inc. v. Henderson, 24 F. Supp. 835, 840-41 (W.D. La. 1938).

76. 1 Black, Judgments $\$ 212$ (1891); Burdick, Service As a Requirement of Due Process in Actions In Personam, 20 MicH. L. Rev. 422, 425 (1922).

77. Prior to the adoption of the Federal Rules, a defendant had to enter a special appearance in order to preserve his objections to the court's jurisdiction. If he first attempted to plead to the merits, he was said to have entered a general apperance and waived those objections. Farkness v. Hyde, 98 U.S. 476, 479 (1878). But the Federal Rules abolished the distinction between the general and special appearance. 2 Moore $\{12.12$. The term general appearance, therefore, does no more than state a legal conclusion, namely that one is before the court and can no longer contest its jurisdiction, an occurance possible under the Rules only when an attack upon jurisdiction is not timely made. FED. R. Crv. P. 12(h). The notion of a general appearance as a plea to the merits which will confer jurisdiction upon the court is no longer accurate under the Rules. The term exists merely to describe an alternative to service of process as a means by which jurisdiction over the person is acquired, though the means is substantively rather vague. 
Joinder of the controlling manufacturer could be effected in the following manner. The patentee would request the opposing counsel to indicate who was controlling the defense, and if control by the manufacturer were thereby revealed, the patentee would move for joinder. Two considerations dictate that this procedure be permitted only before trial: first, the court has an interest in the open participation of all parties from the start of the action, since rights can be adjudicated with greater certainty and fairness if the parties to the dispute appear openly in court throughout the proceedings. Second, if the patentee could request joinder at any point in the process, he would likely postpone that request until such time as the outcome of the litigation were reasonably foreseeable. In all fairness, the status of a participant in an adversary proceeding should not be determined by the tactical interests of his opponent. ${ }^{78}$

It is expected that the patentee would, in most instances, seek to join the manufacturer, since this procedure offers him the opportunity, heretofore unavailable under the patent venue statute, ${ }^{79}$ to proceed directly against the manufacturer for compensatory and injunctive relief in the jurisdiction of his choice. From the manufacturer's point of view, an admission of control following a pre-trial request for such admission would usually be advantageous. Should he win after having admitted control, the possibility of a later suit by the patentee against the manufacturer or any of his customers in regard to the same product would be effectively foreclosed. ${ }^{80}$ But should the manufacturer win after having denied control, equitable considerations would require that he be estopped from later pleading it. In that event, the manufacturer might reasonably expect to face the same patentee complaining about the same infringement by the same product in a subsequent action. Few manufacturers would be willing, even if able, to incur the vast expenses of controlling a patent suit and then deprive themselves of one of its most important benefits. On the other hand, because of obligations to his distributor and possible danger to the reputation of his product, complete abandonment of control is usually not a practical alternative. If the manufacturer assumes control but, for some reason, denies such participation, it is questionable whether the patentee would be able to prove control at the beginning of the suit and before trial. Since at that stage there could be little evidence of actual control, much reliance would have to be placed upon evidence of intent, at best an inconclusive basis on which to rest a finding of fact. There is the possibility of waiting until a later point in the proceedings when retrospective evidence of control might be available to the patentee. But considerations of judicial orderliness, including the impropriety of interrupting the trial to delve into a collateral issue, warn against such a procedure.

78. Fairness to the non-party also demands that, after joinder is requested, he be given a reasonable time prior to trial in which to make any change in his defense that his new status might require.

79. See note 35 supra.

80. See note 27 supra. 
Several policy considerations argue for the court's assumption of jurisdiction over the controlling non-party. Joinder of the manufacturer would eliminate the second suit that a patentee, victorious in an action against a distributor, usually brings against the manufacturer who controlled on behalf of the distributor. ${ }^{81}$ Since the manufacturer is estopped from raising those defenses argued in the prior suit, ${ }^{82}$ such suit is a needless waste of time and resources, a luxury which an already over-crowded court system can ill afford. ${ }^{83}$ Additionally, the oft-deplored game of hide-and-seek so common to the control situation would be eliminated. ${ }^{84}$ Upon the admission of control, those whose ultimate interests are at stake would become parties of record and fully and directly subject to the court's powers. It might be argued that joinder would severely handicap the manufacturer, since it would deprive him of his right to withdraw control should his relationship to the distributor be so altered during the course of the trial as to remove his reasons for control. ${ }^{85}$ The fact remains, however, that his decision to assume control was largely based on an interest in protecting the good name of his product and securing the benefits of estoppel in subsequent suits, and that interest remains despite any changes in his relationship to the distributor. ${ }^{86}$

An increased incentive to forum-shop might provide a more substantial objection to the proposed method of joinder. Now that he can acquire

81. See, e.g., Warford Corp. v. Bryan Screw Mach. Prods. Co., 44 F.2d 713 (6th Cir. 1930). Success in a suit against a distributor does not aid the patentee in halting the manufacturer's sales to other distributors. Because an injunction requires in personam jurisdiction, 7 MOORE If 65.13 , such sales can only be enjoined by a direct suit against the manufacturer. "[I]t is not the act described which the decree may forbid, but only that act when the defendant does it." Alemite Mfg. Co. v. Staff, 42 F.2d 832, 833 (2d Cir. 1930).

82. See note 17 supra.

83. See generally, Zeisel, Kalven \& Bucheolz, Delay in the Court (1959).

84. One court has summed up in the following terms the efforts of opposing counsel to avoid the estoppel effects of an adverse judgment:

In court, counsel for the real party in interest, with somewhat the same skill as an ostrich seeking to conceal itself, assumes a stranger-like attitude toward the client that hired and paid him. If successful however in the litigation, he immediately seeks to obtain an extension of the effect of the decree to his real, but unidentified client, who becomes as prominent now as he was secreted before. On the other hand, if defeated, his real client is not bound, so it is asserted, because not before the court.

His adversary takes exactly the opposite position. He knows the true status of opposing counsel, knows that his adversary's ostrich-like efforts to conceal his true relations are quite as ineffectual as they are grotesque. $\mathrm{He}$, too, awaits the outcome of the litigation before he becomes certain of his knowledge of the true representation of his adversary. Doherty Reasearch Co. v. Universal Oil Prods. Co., 107 F.2d 548, 549 (7th Cir. 1939).

85. Brief for Respondent, p. 5, Schnell v. Peter Eckrich \& Sons, Inc., 365 U.S. 260 (1961).

86. If the manufacturer were confronted with an uncooperative or disloyal customer and injustice were resulting, the court could possibly issue a protective order or even transfer the manufacturer's part of the case to a more proper forum. Brief for Petitioners, p. 6, Schnell v. Peter Eckrich \& Sons, Inc., 365 U.S. 260 (1961). 
in personam jurisdiction over a manufacturer in a forum other than those allowed by $1400(\mathrm{~b})$, it is arguable that the patentee will be more tempted than ever to seek out a forum favorable to patents. Whether, in fact, the temptation will be much greater than that which already exists and finds gratification in suits against distributors rather than manufacturers ${ }^{87}$ is a matter of conjecture. In any case, it can be mitigated by forbidding the patentee to use his extra-statutory forum to present claims not involving the same product which prompted the suit against the distributor. Similar to the manner in which it presently exercises discretion under the Federal Rule governing intervention, the district court could prevent the litigation from expanding far beyond the scope of the original complaint. ${ }^{88}$

Moreover, a liberal interpretation of the Declaratory Judgment Act ${ }^{80}$ will help offset whatever advantages may accrue to the patentee by virtue of his ability to forum-shop. Although the plaintiff has the traditional right to institute suit in the forum of his choice, the criteria for decision should relate to convenience rather than to any supposed predispositions of the courts. ${ }^{90}$ Recognizing, however, that if these predispositions exist, they will not be ignored, little else can be done, absent remedial legislation restricting the accessibility of alternative forums, than to give the parties an equal opportunity to avail themselves of favored jurisdictions. ${ }^{91}$ Thus, if the manufacturer can institute

87. See notes 19 and 20 supra and accompanying text.

88. Under Federal Rule 24,

the court may properly deny or limit permissive intervention where it feels that the interposition of counterclaims not related to the matters at issue between the plaintiff and the defendant would unduly delay or complicate the determination of those issues. 4 MOORE $\llbracket 24.17$ at 135 .

To prevent the litigation from proliferating, it might occasionally be necessary for the court to impose limitations on the scope of the evidence even where only the original product is involved. If, for example, the distributor's infringement consists of using the manufacturer's product in a patented process, a decree in favor of the patentee would only enjoin that particular use, leaving unaffected those who use the manufacturer's product in different but nevertheless infringing ways. Assuming the controlling manufacturer's joinder, the patentee would wish to enjoin the manufacturer from contributing to these other infringing uses. This would require the introduction of a great deal of additional evidence in order first to show that these uses were in fact infringing. Though this procedure would doubtlessly be open to the patentee in a direct suit against the manufacturer, it should be denied him when he is confronting the manufacturer in a suit orginally prosecuted against the distributor. In the large number of cases where a distributor merely uses or resells the product in the same form that he receives it from the manufacturer, this problem will not be raised, and an injunction against the distributor and manufacturer will prevent sales to other distributors.

89. 28 U.S.C. $\$ 2201$ (1958).

90. One district judge has remarked that "a litigant is open to the charge of forumshopping whenever he chooses a forum with slight connection to the factual circumstances surrounding his suit." Rayco Mfg. Co. v. Chicopee Mfg. Corp., 148 F. Supp. 588, 593 (S.D.N.Y. 1957).

91. No claim is made that giving the manufacturer the power to forum-shop on a - competitive basis with the patentee will further the Congressional policy, embodied in $\S$ 
a declaratory judgment suit before the patentee can commence his infringement suit, he will be likely to succeed in litigating the dispute in the jurisdiction of his choice, for, other things being equal, a court will forebear from deciding an issue which is already under consideration in a sister jurisdiction. ${ }^{92}$ How effective this procedure will be depends on the strictness with which the courts construe the requirement that there be an "actual controversy"93 prior to a suit under the act. Narrowly construed, it gives the patentee a decided advantage, for the manufacturer can take no action until the patentee has made a charge of infringement. ${ }^{94}$ As a result, the right to act first belongs to the patentee, and this first act may well be the filing of an infringement suit in a friendly jurisdiction. But a broader construction of the Declaratory Judgment Act permits the manufacturer to take the initiative if he has reason to anticipate an infringement suit against him. ${ }^{95}$ If the action can be as conveniently adjudicated in the forum chosen by the manufacturer as in the one chosen by the patentee, the fact that the manufacturer institutes suit prior to the patentee allows him to enjoin an infringement against him or one of his customers. ${ }^{90}$

1400 (b), of limiting the number of forums in which a patent dispute may be litigated. But inasmuch as that policy is effectively undermined through the practice of suing distributors, a broadened Declaratory Judgment Act will at least give the manufacturer a means by which he can overcome the patentee's advantage.

92. See Note, 72 Harv. L. Rev. 328, 334-35 (1958). But the Supreme Court has counseled against adherence to a "rigid mechanical solution," urging the courts instead to give "regard to conservation of judicial resources and comprehensive disposition of litigation." Kerotest Mfg. Co. v. C-O-Two Fire Equip. Co., 342 U.S. 180, 183 (1951).

93. 28 U.S.C. \$2201 (1958).

94. See Tremond Co. v. Schering Corp., 122 F.2d 702 (3d Cir. 1941). Because notice of infringement is sufficient basis for a declaratory judgment action, one writer cautions patent owners not to inform infringers of the imminence of an infringement suit. Seidel, Patent Litigation, 1 Prac. Law. 49, 52 (March, 1955). See generally, Note, 62 Harv. L. Rev. 787 (1949) ; Note, 45 Yale L.J. 160 (1935).

95. One commentator suggests that the effectiveness of the Declaratory Judgment Act demands a realization "that harm is done and rights are jeopardized by mere dispute or challenge without any physical attack." BorcHard, DECLARATORY JUDGMENTS at xiv (2d ed. 1941).

96. Ufbain v. Knapp Bros. Mfg. Co., 217 F.2d 810 (6th Cir. 1954). But if it appears that forum-shopping was the principal motivation for the choice of a particular venue, the court may overlook the order in which the suits were brought. Rayco Mfg. Co. v. Chicopee Mfg. Corp., 148 F. Supp. 588 (S.D.N.Y. 1957). 